\title{
Al-Batin Alluvial Fan, Southern Iraq
}

\author{
Varoujan K. Sissakian1, Ahmad T. Shihab ${ }^{2}$, Nadhir Al-Ansari ${ }^{3 *}$, Sven Knutsson ${ }^{3}$ \\ ${ }^{1}$ Consultant Geologist, Erbil, Iraq \\ ${ }^{2}$ Iraq Geological Survey, Baghdad, Iraq \\ ${ }^{3}$ Lulea University of Technology, Lulea, Sweden \\ Email: varoujan49@yahoo.com, ahdsat1975@gmail.com, ${ }^{*}$ nadhir.alansari@ltu.se, sven.Knutsson@ltu.se
}

Received 1 August 2014; revised 26 August 2014; accepted 16 September 2014

Copyright (C) 2014 by authors and Scientific Research Publishing Inc.

This work is licensed under the Creative Commons Attribution International License (CC BY). http://creativecommons.org/licenses/by/4.0/

(C) (7) Open Access

\begin{abstract}
Al-Batin alluvial fan is one of the largest alluvial fans in Iraq, especially in the Iraqi Southern Desert. Its eastern and southern limits form parts of the Iraqi-Kuwait international borders. The fan is deposited by Wadi Al-Batin, the last apex being on the southern limits of the main wide depression formed by the active Abu Jir-Euphrates Fault Zone. The main trend of the fan is almost SW-NE. The length and the maximum width of the fan are $110.192 \mathrm{Km}$ and $119.1 \mathrm{Km}$, respectively, whereas the slope along its length is $0.7^{\circ}$. The fan is covered by gypcrete sheet with thickness varying from $(0.5-1.5) \mathrm{m}$. Four stages were recognized within the fan, which is dated to be Pleistocene in age. The four stages are marked by clear height differences. The deposition of the alluvial fan is highly affected by the activity of the active Abu Jir-Euphrates Fault Zone, which is represented on the surface as a wide shallow depression in which the fan is laid down by Wadi Al-Batin. The continuous deposition of the fan has affected the course of the Euphrates Formation within Hammar Marsh and also the course of Khor Al-Zubair in its upper reaches south of Al-Qurna, where the Euphrates and Tigris rivers merge together. Also there is a trace of ancient distributary of the Euphrates River that was flowing directly to the Arabian Gulf, through an estuary, which is abandoned and does not exist anymore.
\end{abstract}

\section{Keywords}

Alluvial Fan, Dibdibba Formation, Clastic Rocks, Pleistocene, Al-Batin, Iraq

\section{Introduction}

Al-Batin Alluvial Fan is one of the largest fans in Iraq, especially in the Iraqi Southern Desert (Figure 1). It is located in the extreme southeastern part of Iraq, within Basra Governorate, between the Iraqi Southern Desert

*Corresponding author. 


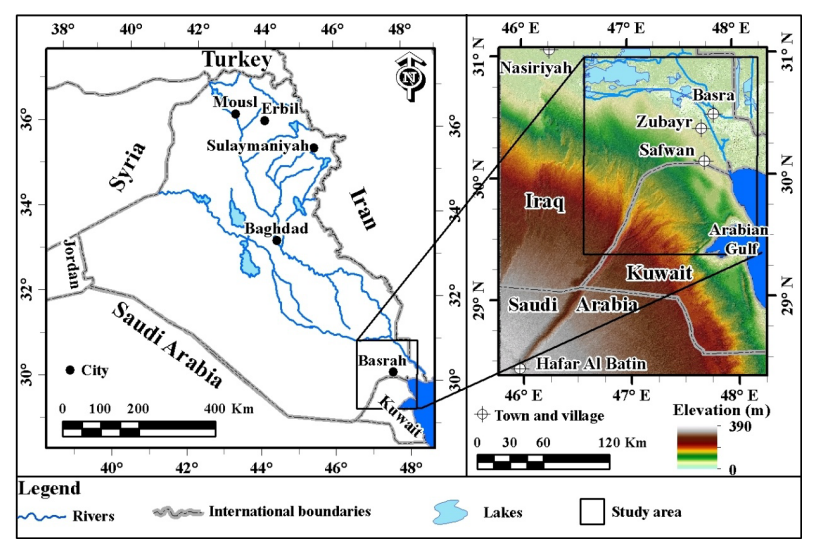

Figure 1. Location map of the studied area Right) color coded of DEMs adopted from Shuttle Radar Topography Mission (SRTM).

and Mesopotamia Plain (Figure 1). However, the majority of the studied area is within the Iraqi Southern Desert.

It consists of four stages; therefore, it is considered as "multi stage large alluvial fan covered by gypcrete" [1]. The length of the fan is about $153.8 \mathrm{Km}$, whereas its maximum width is about $119.1 \mathrm{Km}$; however, the length from the outlet of the valley is only $110.192 \mathrm{Km}$. The fan is deposited by Wadi Al-Batin, which flows in SWNE trend and has deposited its load as fan in the wide and shallow depression formed by the active Abu JirEuphrates Fault Zone [2]-[4].

The aim of this research is to discuss the depositional history of the Al-Batin Alluvial Fan as related to the tectonics and climatic changes. Moreover, different geological characteristics of the fan are given too with new ideas about the courses of the Euphrates River and Khor Al-Zubair.

\section{Materials Used and Method of Work}

To achieve the aim of this research, the following materials were used:

-Geological maps, at scale of 1:100,000, 1:250,000 and 1:1,000,000

-Topographical maps, at scale of 1:100,000 and 1:250,000

-Geological reports concerning this study

-Google Earth, DEM and Satellite images

-Relevant published articles and thesis

-GIS techniques and programs to indicate some numerical data concerning the alluvial fan.

The geological and topographical maps with the Google Earth, DEM and Satellite images were used to recognize the indications of the four stages and the shifting of the Euphrates and Shat Al-Arab Rivers. GIS techniques were used to calculate the coverage area and other geometrical parameters of the alluvial fan with its four stages. Different geological reports, historical and relevant scientific published articles were reviewed to indicate the depositional history of the fan. Some structural and geophysical data were also reviewed to elucidate the relation between the subsurface geology and the position and shape of the fan.

The new global digital elevation model (DEM) produced by the Ministry of Economy, Trade and Industry (METI) of Japan and the United States National Aeronautics and Space Administration (NASA) optical stereo data acquired by the Advanced Spaceborne Thermal Emission and Reflection Radiometer (ASTER) were used. The ASTER Global DEM (GDEM) V.2 was released to the public on June 29, 2009 [5]. ASTER GDEM with spatial resolution of $30 \mathrm{~m}$ was used to determine the boundaries of the alluvial fan's four stages by natural break classification and derived topographical contour lines. In addition, DEMs adopted from Shuttle Radar Topography Mission (SRTM) V.4.1 with spatial resolution of $90 \mathrm{~m}$ was used for hill shade and relief image. Landsat 8 Operational Land Imager (OLI) and Thermal Infrared Sensor (TIRS) launched in February 11, 2013 [6]. The acquisition of available free Landsat 8 OLI and TIRS images were procured through USGS website. One scene of Landsat 8 OLI and Thermal Infrared Sensor (TIRS) images were collected, the details are viewed in Table 1. All bands, except bands 8, 9 and thermal bands 10 and 11 were stacked and used in color composite in this research. 
Table 1. Image characteristics of Landsat 8 OLI and TIRS scene.

\begin{tabular}{|c|c|c|}
\hline Instrument & \multicolumn{2}{|c|}{ Landsat 8 OLI and TIRS } \\
\hline Acquisition Date & \multicolumn{2}{|c|}{ 20/09/2013 } \\
\hline Path/Row No. & \multicolumn{2}{|c|}{$166 / 39$} \\
\hline \multirow{12}{*}{ Spectral Bands ( $\mu \mathrm{m})$} & Bands & Wavelength (micrometers) \\
\hline & Band 1-Costal aerosol & $0.43-0.45$ \\
\hline & Band 2-Blue & $0.45-0.51$ \\
\hline & Band 3-Green & $0.53-0.59$ \\
\hline & Band 4-Red & $0.64-0.67$ \\
\hline & Band 5-Near-Infrared & $0.85-0.88$ \\
\hline & Band 6-SWIR 1 & $1.57-1.65$ \\
\hline & Band 7-SWIR 2 & $2.11-2.29$ \\
\hline & Band 8-Panchromatic & $0.50-0.68$ \\
\hline & Band 9-Cirrus & $1.36-1.38$ \\
\hline & Band 10-Thermal Infrared (TIRS) 1 & $10.60-11.19$ \\
\hline & Band 11-Thermal Infrared (TIRS) 2 & $11.50-12.51$ \\
\hline Spatial Resolution & \multicolumn{2}{|c|}{$15 \mathrm{~m}$ for panchromatic band, $30 \mathrm{~m}$ for multispectral bands and $100 \mathrm{~m}$ for thermal bands } \\
\hline Radiometric Resolution & \multicolumn{2}{|c|}{ 16-bit pixel values } \\
\hline
\end{tabular}

ERDAS IMAGINE V.13 software was used to perform the data, e.g. (layer stack and subset). ArcGIS V.10.0 software was also used to digitize topographical features, stages of alluvial fan, derived topographical contour lines, construction topographic cross section, extraction shaded relief image and layout the results.

\section{Previous Work}

Different studies had been carried out concerning Al-Batin alluvial fan, but none of them has dealt with its depositional history and the effect of the fan on the shifting the course of the Euphrates and Shat Al-Arab Rivers. The present studies have dealt with different geological aspect; the most related studies are mentioned hereinafter.

-Al-Sharbati and Ma'ala [7] had recognized four stages of alluvial fans of Wadi Al-Batin, they mentioned about the details of the alluvial fan.

-Deikran [8] [9] described the details of the alluvial fan.

-Hamza [10], in the Geomorphological Map of Iraq, mentioned the presence of gypcrete covering the alluvial fan.

-Barwary et al. [11], in the Quaternary Sediments Map of Iraq also referred to the gypcrete that covers the top surface area of the alluvial fan.

-Sissakian and Ibrahim [12], in the Geological Hazards Map of Iraq mentioned about the gypcrete covering the top surface area of the alluvial fan.

-Fouad [2]-[4] mentioned about the depression that represents the active Abu Jir-Euphrates Fault and its extension to the studied area.

-Jassim and Al-Jiburi [13] described the sediments of the alluvial fan and that of the Dibdibba Formation. They also mentioned the constituents of the alluvial fan.

-Ma'ala [14] wrote about the geomorphological aspects of the alluvial fan.

-Yacoub [15] [16] described the composition of the alluvial fan.

-Sissakian and Abdul Jab’bar [1], considered Al-Batin Alluvial Fan as “multistage, large alluvial fan covered by gypcrete". 


\section{Geologic Setting}

The geology of the involved area is described briefly, hereinafter. It includes: geomorphology, structure and tectonics and stratigraphy; depending on Al-Sharbati and Ma’ala [7], Diekran [9], Jassim and Al-Jiburi [13], Yacoub [15] [16], Fouad [4] and Sissakian and Fouad [17].

\subsection{Geomorphology}

The main geomorphological unit in the studied area is Al-Batin Alluvial Fan. Al-Batin Alluvial Fan, is one of the ideal cases of alluvial fans of a desert plateau. It comprises essentially of ill-sorted gravely sand, with gypcrete top cover. The size of the gravels varies from coarse gravels (5 - $20 \mathrm{~cm}$ ), around the apex of the fan, to fine gravels and pebbles $(2-5 \mathrm{~cm})$, in the peripheral parts. The thickness of the gypcrete varies from $(0.5-1.5) \mathrm{m}$ [15] [16]. The present day fan was formed in four stages. The stages are concentric with parallel iso-transport energy lines forming concentric arcs about the discharge point, having typical fan shape for all the stages; almost with flat top and very gentle gradients, small break separates between the four stages. It is very long fan; attaining110.192 Km. The length of the fan during the four stages were measured by ArcGIS technique. They were: $36.916 \mathrm{Km}, 12.860 \mathrm{Km}, 33.438 \mathrm{Km}$ and $26.978 \mathrm{Km}$ for the four stages respectively, whereas the coverage areas is about $10842 \mathrm{Km}^{2}$. The feeder channel is one of the largest valleys in the Iraqi Southern Desert called Al-Batin valley. It is still active, but had changed the location its course, being now in the extreme eastern part of the fan body, and almost without feeding the fan with new sediments, due to climatic changes, especially the annual precipitation, as confirmed by given [18].

Other geomorphological units and forms are: Estuarine sabkha, Inland sabkha, gypcrete, flood plain sediments, sand sheets and sand dunes, depression fill sediments, dry marsh, active marsh (Figure 2). Because all these units have no significant importance, which concern this study; therefore they are not described. The details can be seen on the aforementioned references. However, Jabal Sanam is an outstanding geomorphological feature; located east of the alluvial fan (Figure 2).

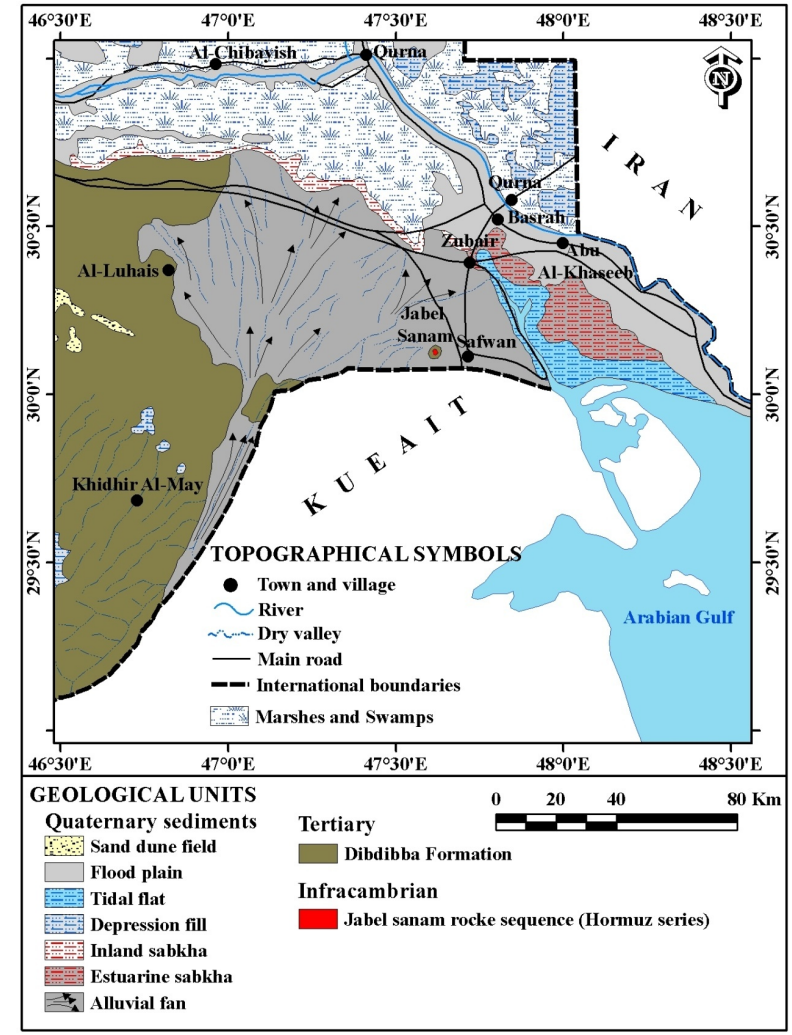

Figure 2. Geological map of the studied area [17]. (The four stages of the alluvial fan are distinguished by four sets of arrows). 


\subsection{Tectonics and Structural Geology}

The studied area is located within two different tectonic zones. The lower half part is within the Inner Platform of the Arabian Plate, whereas the upper half parts is located within the Outer Platform; represented by the Mesopotamia Foredeep, of the Arabian Plate [4]. The contact between the two tectonic zones is represented on the surface by a wide shallow depression, which is formed due to the active Abu Jir-Euphrates Fault Zone [2]-[4]. Moreover, Fouad [2] [3] pointed out that Abu Jir Fault Zone exhibits some geomorphologic features (pressure ridges and sag ponds) that are related to the lateral movement of the active fault zone. The studied area shows no any structural evidence for presence of structural element. However, some lineaments (Figure 3) within the alluvial sediments may indicate active structural forms; otherwise they shouldn't appear in the sediments.

\subsection{Stratigraphy}

The pre-Quaternary rocks are presented only by the Dibdibba Formation. Many other Quaternary types of sediment are present too in the studied area, but only the sediments of the alluvial fan besides the Dibdibba Formation are described briefly based on Al-Sharbati and Ma'ala [7], Diekran [9], Jassim and Al-Jiburi [13] and Yacoub [16]; hereinafter.

-Dibdibba Formation: The Dibdibba Formation is exposed in the studied area (Figure 2). Although it covers extensive areas, the thickness ranges from 3 to $8 \mathrm{~m}$ [7]. The Dibdibba Formation comprises of poorly sorted sand and sandstone; together with gravels. The sand and sandstone are mostly quartz; they consist of about $84.2 \%$ quartz grains of mono-crystalline and crystalline types, with around $8.5 \%$ of rock fragments and $7.3 \%$ of feldspar. The Dibdibba gravels consist mainly of acidic and intermediate igneous rocks, with smaller amount of metamorphic rocks, limestone and chert (Sadik, 1977 in [19]).

The age of the Dibdibba Formation is a matter of argument; it is assumed to be Late Miocene-Pliocene to Early Pleistocene [20]. However, Jassim and Buday in [21] claimed its age to be post Middle Miocene and Late Miocene-Pliocene, whereas Sissakian and Mohammed and Sissakian and Fouad [17] [22] suggested PliocenePleistocene age, which is adopted by the current authors.

It is worth mentioning that the differentiation between the Dibdibba Formation from Al-Batin Alluvial Fan sediments depends on the type of the cementing material of the sandstone beds. The sandstones of Dibdibba Formation are commonly cemented by calcareous material, whereas gypsiferous cementing materials are prevailing in Al-Batin Alluvial Fan sediments.

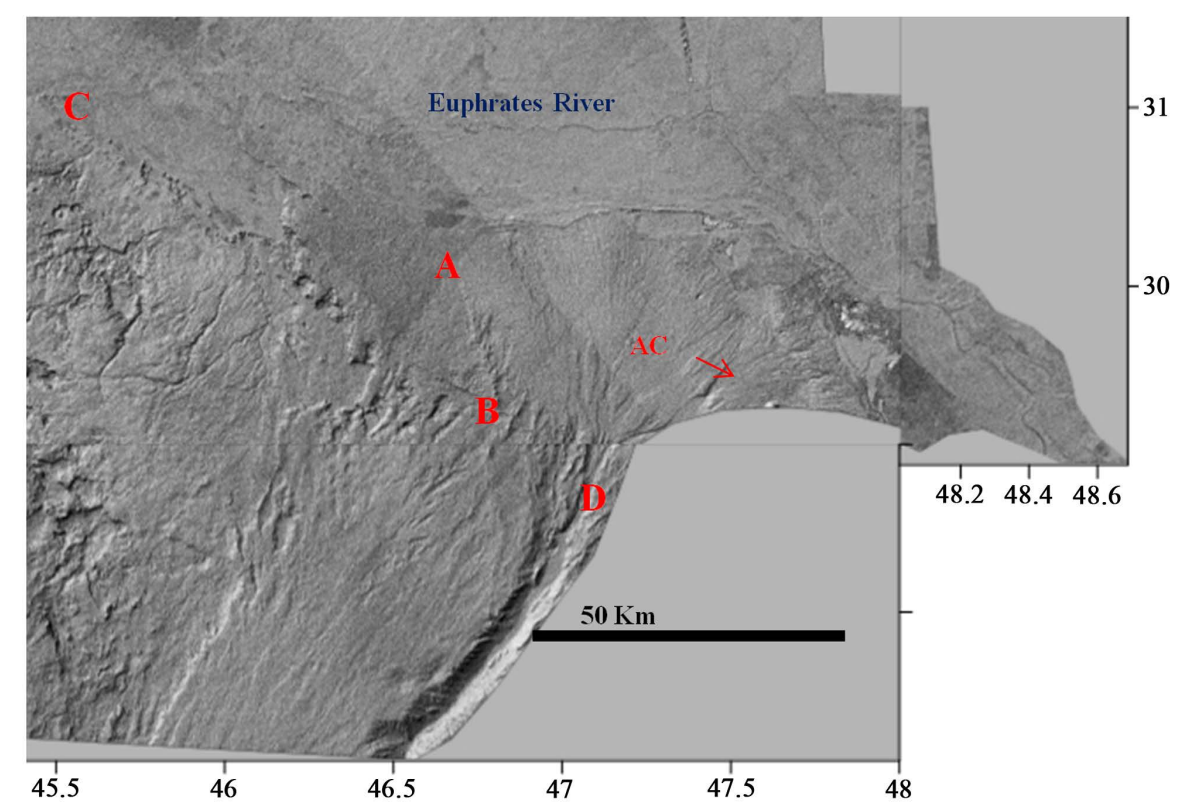

Figure 3. Shaded relief image derived from DEMs of SRTM of the studied area. Note the NNW-SSE lineament (A - B), C - D is the southern limit of the depression, which represents the Abu Jir-Euphrates Fault Zone, AC is an ancient distributary course of the Euphrates River. 
-Al-Batin Alluvial Fan: It is one of the ideal cases of alluvial fans of a desert plateau. It comprises essentially of ill-sorted gravely sand, sandy gravel and gypcrete, with subordinate layers and lenses of silty and sandy clay. The sands and gravels are composed mainly of quartz and feldspars, with less limestone pebbles and occasional acidic igneous and volcanic rock fragments. Aqrawi et al. (2006) in [13] also mentioned the presence of heavy mineral assemblages, mostly of rutile and zircon; in these sediments. These heavy minerals prove the origin of the sediments to be derived from the Arabian Shield. The sands are commonly medium to coarse grained, occasionally pebbly, yellowish pink in color, which might be derived from erosion of the Fluvial Plain (Dibdibba Formation). The erosional materials are transported by Al-Batin stream during the Pleistocene. The apex of the fan is characterized by gravelly sand, whereas its toe, near Hor Al-Hammar, has fine and friable sands [7]. The gravels form thin lenses, lenticular beds, reach up to $2 \mathrm{~m}$ in thickness, or randomly scattered within the sand beds. The size of the gravels varies from coarse gravels (5 - $20 \mathrm{~cm}$ in size), around the apex of the fan in the main channel of Wadi Al-Batin, to fine gravels and pebbles (2 - $5 \mathrm{~cm}$ in size), in the peripheral parts of the fans. Planar bedding, cross-bedding and gravel lag are common fluvial sedimentary structures in this fan system. The gypcrete and gypsiferous cementing material are fairly common in surface beds. The thickness of the gypcrete beds varies in average between (0.5 - 1.5) $\mathrm{m}$ [16].

\section{Characteristics of Al-Batin Alluvial Fan}

Al-Batin Alluvial Fan is considered as "multi (four) stages, large alluvial fan covered by gypcrete" [1]. The length of the fan is $110.192 \mathrm{Km}$, whereas its width is $119.1 \mathrm{Km}$. The lengths of the exposed parts of the four stages are $36.916 \mathrm{Km}, 12.860 \mathrm{Km}, 33.438 \mathrm{Km}$ and $26.978 \mathrm{Km}$, respectively from the 4th stage to the 1st, whereas the coverage area of the fan is about $10842.858 \mathrm{Km}^{2}$. The thickness of the fan is not determined, but the thickness of the covering gypcrete layer ranges from (0.5 - 1.5) $\mathrm{m}$ [16].

The four stages are differentiated from each other by a break in the slope [15], they are represented by four sets of arrows in Figure 2. The four stages indicate break in deposition during Pleistocene and may be from Late Pliocene. The feeder channel is Wadi Al-Batin, which has shifted its course towards east of the fan main body (Figure 4); representing nowadays international boundaries between Iraq-Kuwait-Saudi Arabia. Wadi Al-Batin is one of the largest and longest valleys not in the studied area, but in surrounding areas too (Figure 4).

The four stages of Al-Batin Alluvial Fan have different coverage areas. The boundaries of the four stages were determined based on natural break classification of the ASTER GDEM. ArcGIS technique was used to calculate the true and exposed coverage areas of each stage. The details are mentioned in Table 2. Moreover the limits of the four stages are shown in Figure 5.

Contour lines in interval of $10 \mathrm{~m}$ were constructed from ASTER (GDEM) and manifested over Landsat $8 \mathrm{im}$ age (OLI) R:G:B 7:5:2 (Figure 6, Left) and over SRTM-DEM in hill-shaded mode (Figure 6, Right), using GIS technique. The constructed contour lines show the uniform shape of the fan and coincide with isolines radiated from the apex. The trace of the feeder channel (Wadi Al-Batin) is clearly visible in the contour lines, it was flowing directly northeastwards, but was shifted towards east, forming the nowadays course.
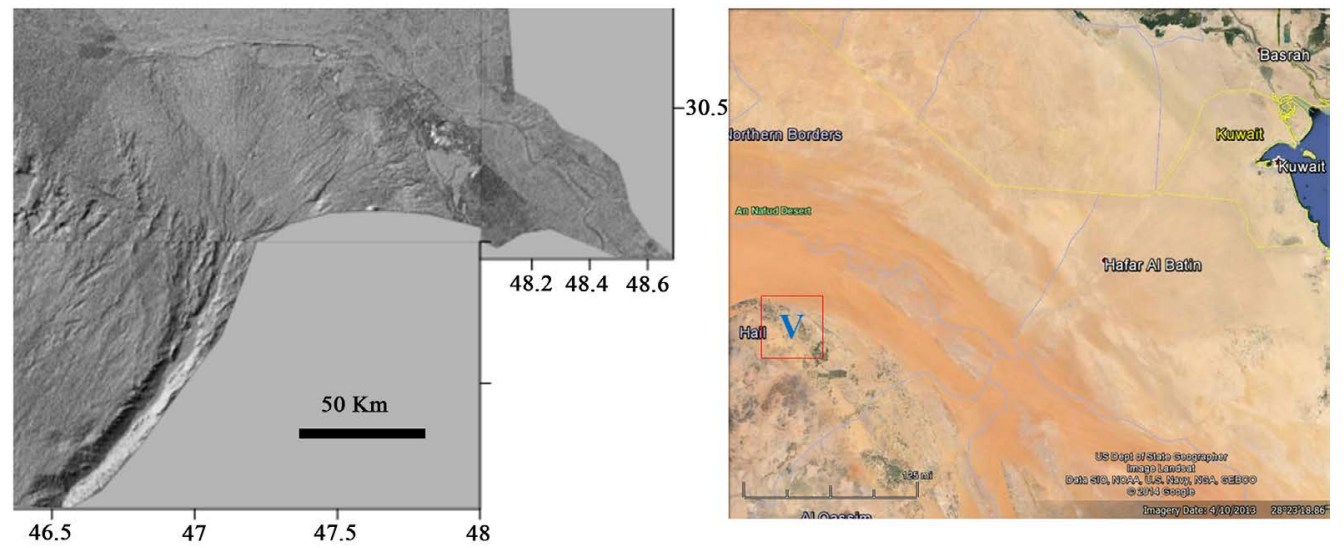

Figure 4. (Left) DEM in hillshaded mode image of Al-Bat in Alluvial Fan, note the width and depth of AlBat in valley; (Right) Google Earth image, note the length of the valley in Saudi Arabia, V = Starting point of the valley, its course is visible northeastwards. 


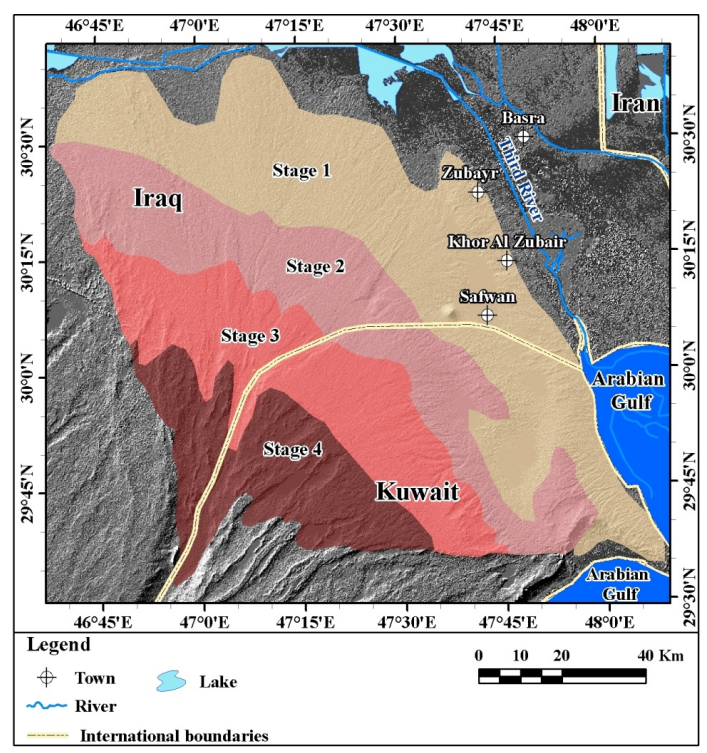

Figure 5. SRTM-DEM in hillshaded mode overlying by the four stages of Al-Bat in Alluvial Fan.
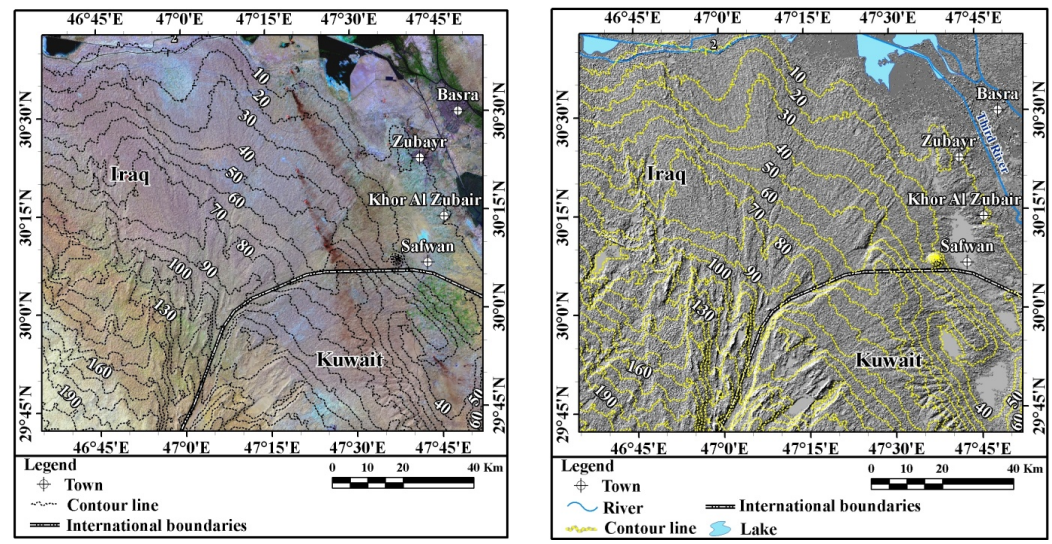

Figure 6. (Left) Landsat8 (OLI) R:G:B 7:5:2 overlain by contour line derived from ASTER GDEM; (Right) SRTM-DEM in hill shaded mode with contour line layer [6].

Table 2. Coverage area of the four stages of the alluvial fan.

\begin{tabular}{ccc}
\hline Stage & Exposed area $\left(\mathbf{K m}^{2}\right)$ & True area $\left(\mathbf{K m}^{\mathbf{2}}\right)$ \\
\hline 1 & 4204.194 & 10842.858 \\
2 & 2661.766 & 6638.664 \\
3 & 2257.373 & 3976.898 \\
4 & 1719.525 & 1719.525 \\
\hline
\end{tabular}

The slope of the alluvial fan's four stages was calculated using the following formula and the results are mentioned in Table 3:

$$
\alpha=\tan -1 \Delta Z / D
$$

where:

$\alpha$ is the slope angle; 
Table 3. Slope angle of the four stages of the alluvial fan along profile section A - B.

\begin{tabular}{ccccc}
\hline Stages & Distance $(\mathbf{K m})$ & Max. Elevation $(\mathbf{m})$ & Min. Elevation $(\mathbf{m})$ & Slope value (degree) \\
\hline 1 & 36.916 & 48 & 15 & 0.051 \\
2 & 12.860 & 80 & 48 & 0.142 \\
3 & 33.438 & 112 & 80 & 0.054 \\
4 & 26.978 & 153 & 112 & 0.087 \\
Total & $\mathbf{1 1 0 . 1 9 2}$ & $\mathbf{1 5 3}$ & $\mathbf{1 5}$ & $\mathbf{0 . 0 7 1}$ \\
\hline
\end{tabular}

$\Delta Z$ is the difference in elevation between the maximum and minimum elevation along profile section; $D$ is the distance between the maximum and minimum elevation.

\section{Results}

Al-Batin Alluvial Fan is a very large fan, $110.192 \mathrm{Km}$ in length and coverage area of $10842.858 \mathrm{Km}^{2}$, with four stages. The fan is covered by gypcrete, being deposited in a depression that is formed by the active Abu JirEuphrates Fault Zone. The continuous deposition of the fan with such extremely large valley; as the main feeder channel, has covered the depression and extended farther northeast wards and had shifted the Euphrates River and an ancient distributary course of the river (Figure 3). However, the main feeder channel is shifted eastwards (Figure 3 and Figure 4), most probably due to the activity of the active Abu Jir-Euphrates Fault Zone. The retreating of the four stages towards the apex and the very low slope angle $\left(0.7^{\circ}\right)$ of the fan surface are good indications for the activity of the depression in which the fan was deposited.

\section{Discussion}

\subsection{Shape and Stages of the Fan}

Al-Batin Alluvial Fan has delta shape (Figures 2-4), with length of $110.192 \mathrm{Km}$ and very wide periphery, since its maximum width is $119.1 \mathrm{Km}$. The fan was deposited by single feeder channel; Wadi Al-Batin, which is one of the largest valleys not only in Iraq, but in near surroundings too (Figure 3 and Figure 4). During the wet phases of the Pleistocene, four stages of the fan were deposited [23].

Figure 5, Figure 7 and Figure 8 show clearly the four stages of the alluvial fan. It is clear that the oldest stage is No. 1 and the youngest is No. 4. Moreover, in the northeastern part of the oldest stage, clear concentric forms occur, which are parallel to the periphery of the oldest stage; indicating continuous retreatment of the fan. However, it also may indicate continuous shifting of the course of the Euphrates River northeastwards due to the continuous growth of the first stage of the alluvial fan. It is believed that the second assumption is more likely.

The two topographic cross sections (Figure 9) show the shape of the alluvial fan. The topography along the slope ((A) and (B) in Figure 9) shows the break in the gradient of the four stages. The clearest break in the gradient is between stages 2 and 3. Whereas, the topography across the fan ((C) and (D) in Figure 9) shows that the eastern side of the fan is higher and steeper, as compared to the western side. This is attributed to regional slope; during deposition, which was towards northeast. Therefore, the coverage area of the fan towards east is more than in the western side of the main feeder channel.

The measured slopes of the four stages (Table 2) and that of the whole fan (about $0.7^{\circ}$ ) contradicts with the assumption of [24], which states that "These findings contrast with a previous notion that depositional landforms rarely have slopes of $0.5^{\circ}(0.009)$ to $1.5^{\circ}(0.026)$ and hence only semi-conical landforms steeper than $1.5^{\circ}$ should be called alluvial fans". However, it is believed that the original slope of the fan body was higher; otherwise the fan wouldn't cover such vast area, but it was flattened due to tectonic activity of the depression.

Figure 7 also shows clearly in the extreme eastern part of the alluvial fan an ancient course (Point AC in Figure 7), which may be a distributary course of the Euphrates River that was draining directly in Khor Al-Zubair. The course was abandoned due to its continuous shifting eastwards, besides the shifting of the Euphrates River northeast wards. The presence of the ancient course is also evidenced by the presence of tens of small valleys draining the alluvial fan to the course. Some of those valleys have deposited small alluvial fans (Point AF in Figure 7). 


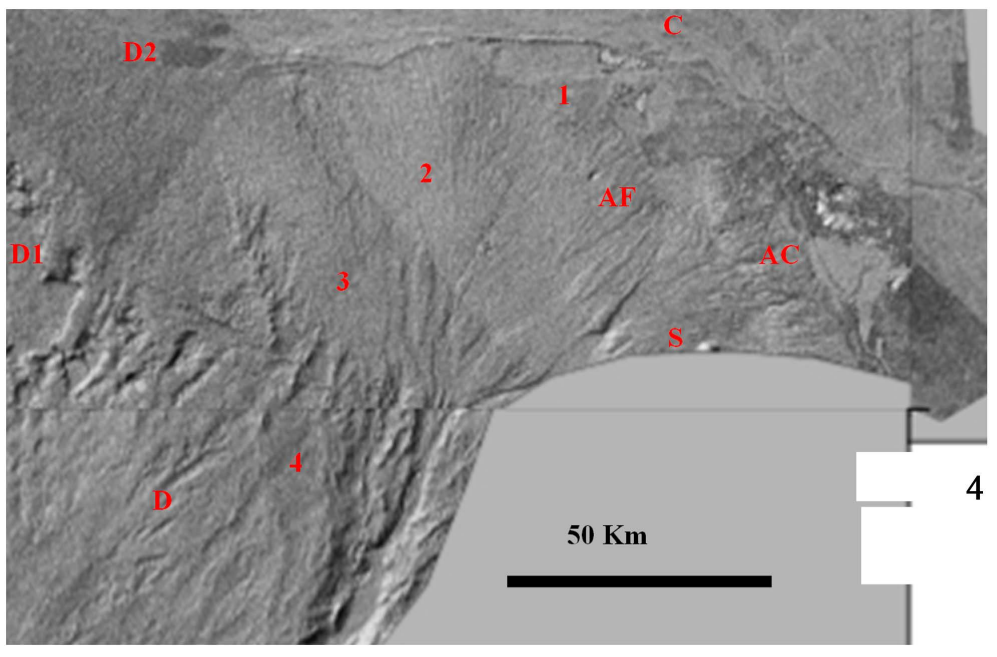

Figure 7. DEM in hillshaded mode image of Al-Batin Alluvial Fan. 1, 2, 3 and 4 are the four stages. Note: $\mathrm{C}=$ Concentric forms, $\mathrm{AC}=$ Ancient course, $\mathrm{D}=$ Dibdibba Formation, AF = Alluvial fans, S = Jabal Sanam, D1 - D2 = Depression width.

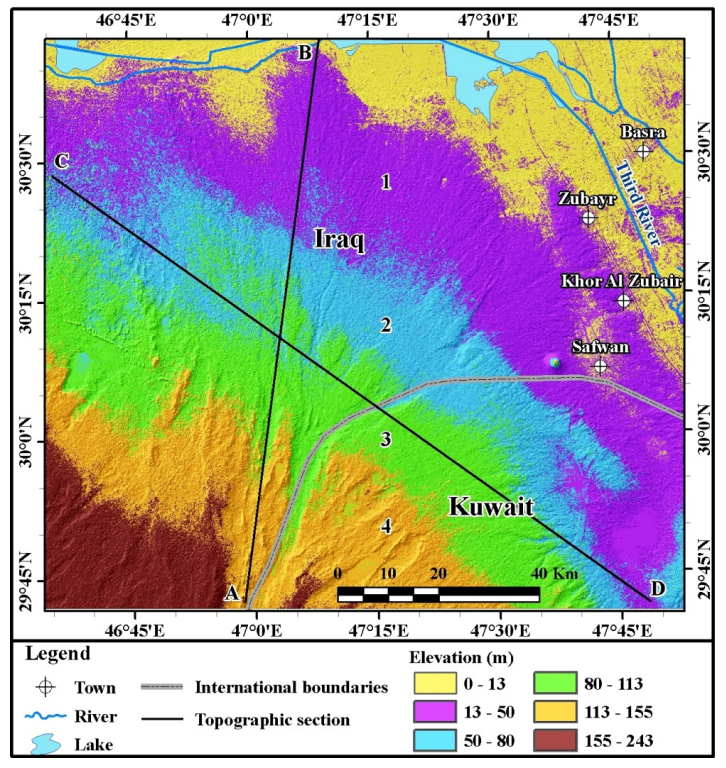

Figure 8. Natural break classification of DEMs adopted from ASTER Global Digital Elevation Model (GDEM) V2. Note the elevation range of the four stages (1, 2, 3 and 4).
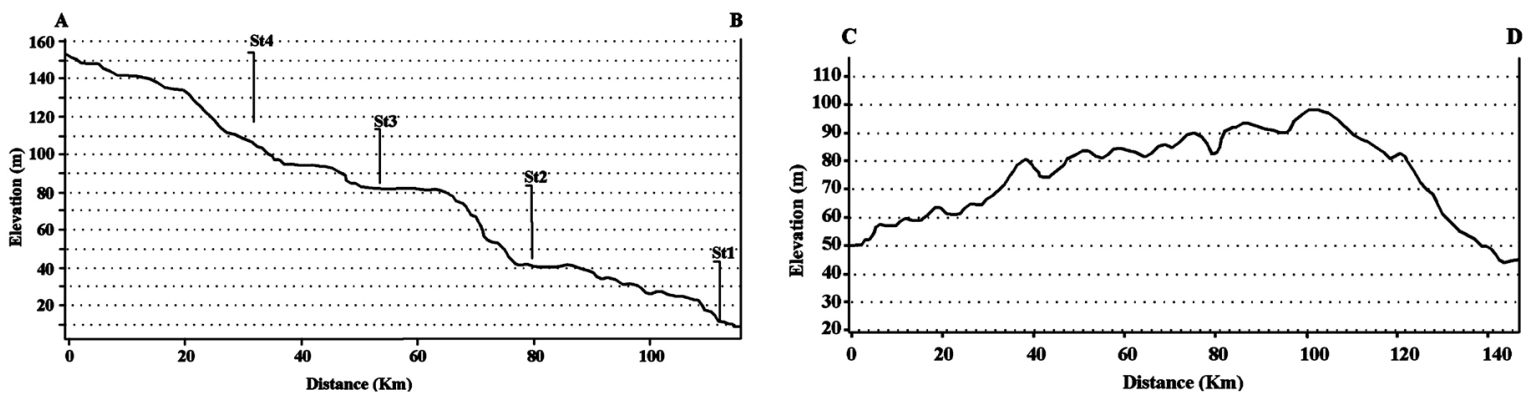

Figure 9. Two topographic sections along lines (A) - (B) and (C) - (D) (Location of both sections are shown in Figure 8). 


\subsection{Dibdibba Formation}

The Dibdibba Formation is known to be fresh water sediments [19] [20]. Sadik (1977) in [19] suggested the environment of the Dibdibba Formation to be fluvial based on the grain size analysis, shape and size of the gravels and the sedimentary structure. According to [19], the Dibdibba Formation represents fluvial sedimentation in extensive sheet probably as large old alluvial fans. From thickness studies, it seems that at least two such fans may be considered. Salman (1984) in [13] Jassim and Al-Jiburi (2009), assumed a fresh water environment to the formation according to its fossil contents. Jassim and Buday in [21] Jassim and Goff (2006) suggested that the formation was deposited in a fresh water environment, becoming deltaic some times.

From the regional geology of Iraq, the Dibdibba Formation is deposited mainly as alluvial fans; like KarbalaNajaf and Al-Batin alluvial fans [7] [17] [25]-[27]. Figure 7 shows the distribution of the exposures of the Dibdibba Formation around Wadi Al-Batin, which gives indication for an ancient fan; before the deposition of AlBatin Alluvial Fan. The "Dibdibba Fan" (it will be called so in the current study) was deposited most probably during Pliocene-lower Early Pleistocene, as the age of the formation is proved to be Pliocene-Pleistocene and as most of the alluvial fans in Iraq have Pleistocene age [1] [13] [15]-[17] [22] [28] [29]. The deposition of the fan was terminated either due to climatic changes (successive wet and dry phases), which have happened during Pleistocene [18] [30] and no more sediments supply was reaching the fan; or due to the uplift of the area, which is less likely. Then Wadi Al-Batin started to dissect the fan body, which is very normal case [31] [32] and formed the main course of the valley, which is still present (Figure 4 and Figure 5 and Figure 7), but not the curved part towards the east; as it is in nowadays course. The wide extension of the Dibdibba Fan towards east is also evidenced by the presence of outcrops of the Dibdibba Formation surrounding the spectacular Sanam Mountain in a circular form (Figure 2), covered by the sediments of the first stage of Al-Batin Alluvial Fan. Otherwise, there is no explanation for the presence of outcrops of the Dibdibba Formation surrounding Sanam Mountain; in a uniform circular form (Figure 2). The presence of radial valleys on the surface of the Dibdibba Fan, especially in the extreme eastern and western sides (Figure 3 and Figure 10) is also evidence that the sediments were laid down as an alluvial fan

After Pliocene and during Early Pleistocene, the sediments supply restarted again and the first stage was laid down (Figure 7). This stage was the largest one; as it can be seen and it was continuously shifting the course of the Euphrates River, as evidenced by successive circular forms (point C in Figure 7). The other three stages were deposited continuously, but with shorter distances. This is attributed to the climatic changes and/ or the activity of the Abu Jir-Euphrates Fault Zone, which is represented by a depression in which the fan was deposited. The traces of the depression below the sediments of the fan (D1 - D2 in Figure 7) can be seen, which has dark tone as compared with the dry surrounding sediments. The retreating of the fan stages towards the apex may indicate tectonic activity in the depositional basin [33]. The activity of the depositional basin is related to the activity of Abu Ji-Euphrates Fault Zone, which is proved to be still active [2]-[4].
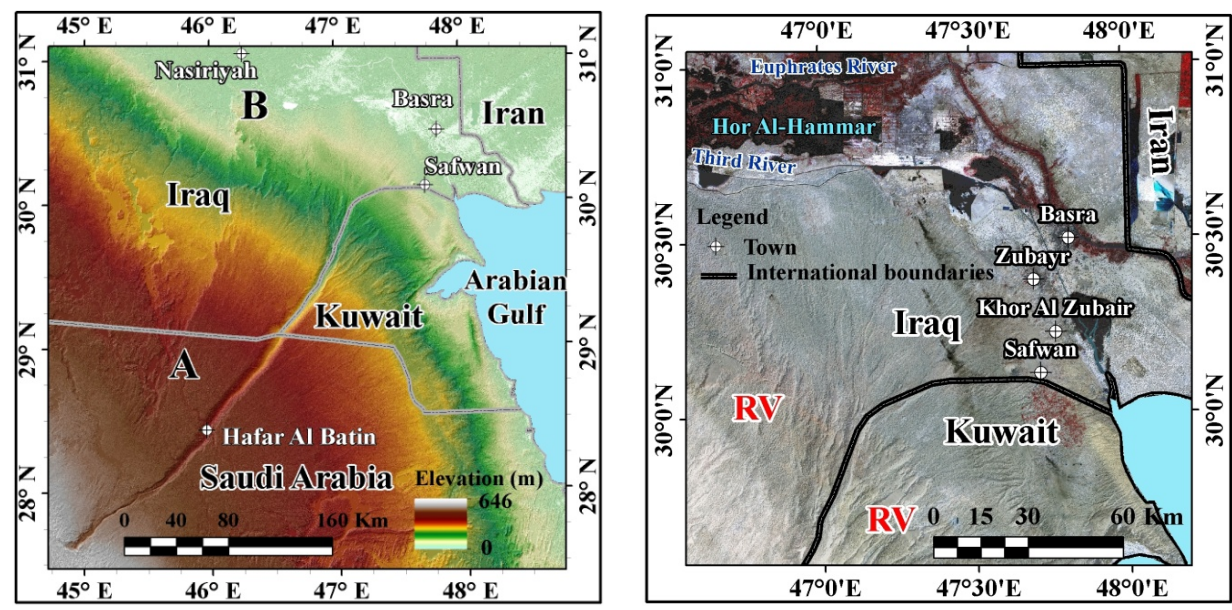

Figure 10. (Left) Color coded of DEMs adopted from SRTM of Al-Batin Alluvial Fan. Note the lineament ((A) - (B)) west of the main feeder channel; (Right) Landsat 8 (OLI) R:G:B 5:4:3. Note the radial valleys (RV) on surface of the Dibdibba Formation. 


\subsection{Activity of the Depositional Basin}

The Southern Desert, during Pliocene-Pleistocene was still uplifted area, due to the collision of the Arabian Plate with the Neo-Tethys terrains (Sanandaj-Serjan zone). Therefore, continental, fluvial deposits prevailed over the area in different forms, among them are alluvial fans. And because the existing valleys were very large, mainly draining from Saudi Arabia; therefore, the deposited alluvial fans are very large, like Al-Batin and Karbala-Najaf Fans [1].

However, medium sized alluvial fans are also present in different parts of the Iraqi deserts, like the Hab'bariyah Fans [29]. All these fans are deposited in depressions, which were active during deposition phases and some of them are still active. The presence of the four stages in Al-Batin Alluvial Fan is a clear indication for the activity of the depression, besides the NNW-SSE lineament within the fan sediments (Figure 3, Figure 6 and Figure 11). This lineament, which is clearly visible in Figure 11 is a good evidence for the activity of the depression, after the deposition of the fan (Late Pleistocene and younger), in which the fan sediments were laid down. It may represent oblique fault; within the depression, such faults are confirmed by [2]-[4]. However, the lineament may represent the ancient course of Wadi Al-Batin during deposition of the "Dibdibba Fan".

When comparing the trend and approximate width of the depression in both images (Figure 11), it can be seen obviously that both of them have the same trend and width. Moreover, it is very clear evidence that the mentioned fault zone is wider, especially west of Al-Batin valley and extends even in the Arabian Gulf, which is not mentioned by [2]-[4] when he defined the boundaries of the tectonic zones in Iraq.

Figure 11 (right) also shows probable ancient irrigational straight and uniform channel, which has white tone; it is dissected by Khor Al-Zubair channels system, indicating tectonic activity that had caused dissection of the irrigation channel (after being abandoned due to tectonic activity and/or climatic changes) and erosion of its banks. The point C (Figure 11, right), which is along the southwestern limit of the depression shows widening in the channel embankments along the southwestern limits of the depression ( $\mathrm{C}$ and $\mathrm{D}$ in Figure 11); indicating tectonic activity within the depression and its near surroundings.

\subsection{The Present Day Form of the Al-Batin Alluvial Fan}

The surface of Al-Batin Alluvial Fan was dissected by water erosion during early Holocene (rainy stage), which produced highly dissected surface due to tens of beheaded valleys (Figure 3, Figure 4 and Figure 7). During the late Holocene (dry stage), the fan surface was influenced by wind erosion, which produced deflation depressions. In these depressions, coarse gravels were led in site to form pavement landform. Most of the deflation depressions are covered by sand drift. However, some of them, which are connected to ephemeral dry valleys, are modified to playas and their muddy sediments cover the residual gravels. Moreover, Al-Batin River was modified to dry valley, which is partly covered by sand drift accumulations and Nebkha [15].
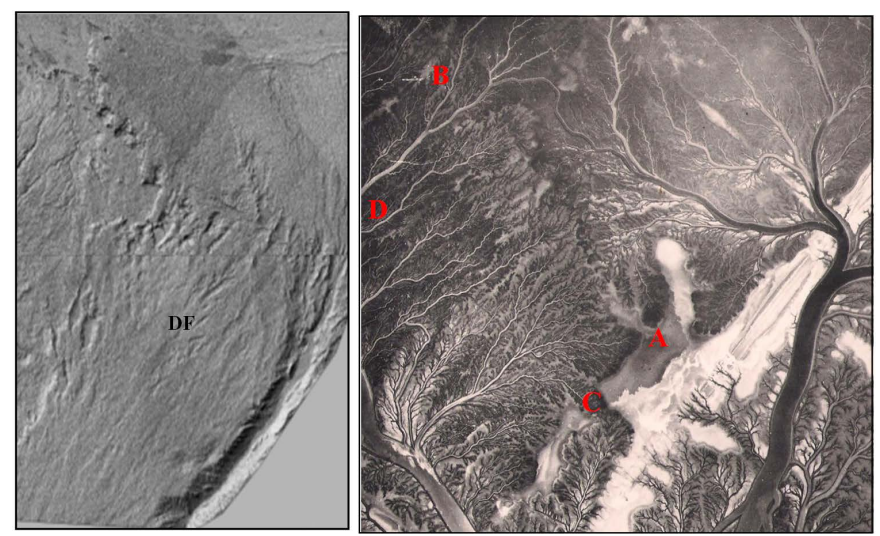

Figure 11. (Left) Hillshde image showing the highly weathered top surface of Dibdibba Fan (DF), note the trace of the extension of the active depression of Abu Jir-Euphrates Fault Zone, below the sediments of the fan; (Right) Aerial photograph shows the tidal channels system of Khor Al-Zubair, [15] Note the extension of the active depression, as expressed by water divide and two parallel lineaments (A - B and C - D), also a clear offset at (C). 
The surface of Al-Batin Alluvial Fan shows also a clear lineament in NNW-SSE trend (Figure 3 and Figure 7), this lineament is within the depression of the active Abu Jir-Euphrates Fault Zone and it may represent one of the pressure ridges, which are present in the depression along the fault zone, besides the sag ponds [3] [4].

The presence of the outcrops of the Dibdibba Formation (Dibdibba Fan) west of Al-Batin Alluvial Fan in higher elevation than the latter fan indicates that the latter fan was deposited in a basin, which was lower than the top surface of the former fan. This is another indication for the activity of the area. The presence of large groves and irregular depressions on the surface of Dibdibba Fan (Figure 7) indicate that the area had suffered from intense erosion by the flowing valleys during wet phases of Pleistocene and Holocene.

\section{Conclusions}

- The four stages of Al-Batin Alluvial Fan are in retreating order, the first stage, which is the most far one from the apex in the oldest stage.

- The exposures of the Dibdibba Formation, west and east of Al-Batin valley represent an older fan (Dibdibba Fan of Pliocene age); older than Al-Batin Fan. The radial streams on the surface of the exposures, besides the depositional environment of the Dibdibba Formation, indicate alluvial fan origin for the sediments.

- The trace of the depression of the Abu Jir-Euphrates Fault Zone is clearly visible under the sediments of Al-Batin Alluvial Fan.

- The sediments of the first stage of Al-Batin Fan have shifted continuously the course of the Euphrates River northeast wards. Moreover, they have shifted an ancient distributary of the Euphrates River that was draining directly in Khor Al-Zubair, and has caused the dryness of the distributary.

- The "Dibdibba Fan" sediments were covering vast areas east of Al-Batin valley. They extend beyond Sanam Mountain and form a circular exposure pattern around the mountain, which is exposed nowadays due to the erosion of Al-Batin Fan sediments.

- A NNW-SSE lineament is visible within the third stage sediments of Al-Batin Alluvial Fan; it may indicate a trace of a pressure ridge within the active Abu Jir-Euphrates Fault Zone.

- The Abu Jir-Euphrates Zone extends southeastwards and becomes wider west of Khor Al-Zubair and most probably extends across the Arabian Gulf too.

- The nowadays slope of the surface of the alluvial fan is not the original slope, since it is flattened due to tectonic activity of the depression in which it is deposited.

\section{Acknowledgements}

The authors would like to Professor Ian Foster for reading the manuscript and giving fruitful suggestions.

\section{References}

[1] Sissakian, V.K. and Abdul Jab’bar, M.F. (2014) Classification of Alluvial Fans in Iraq. Iraqi Bulletin of Geology and Mining, 10. (in Press)

[2] Fouad, S.F.A. (2004) Contribution to the Structure of Abu Jir Fault Zone, West Iraq. Iraq Geological Journal, 32-33, 63-73.

[3] Fouad, S.F.A. (2007) Tectonic and Structural Evolution of the Iraqi Western Desert. Iraqi Bulletin of Geology and Mining, Special Issue, 29-50.

[4] Fouad, S.F.A. (2012) Tectonic Map of Iraq, Scale 1:1000000. 3rd Edition GEOSURV, Baghdad.

[5] ASTER GDEM Validation Team (2009) ASTER Global DEM Validation Summary Report, 28.

[6] USGS (2013) Landsat 8 Operational Land Imager (OLI) and Thermal Infrared Sensor (TIRS) http://landsat.usgs.gov/band_designations_landsat_satellites.php

[7] Al-Sharbati, F. and Ma'ala, K. (1983) Report on the Regional Geological Mapping of West of Zubair Area. GEOSURV, Inernal. Report No. 1345.

[8] Deikran, D.B. (1994) The Geology of Ar-Rukhaimiya and Kuwait Quadrangles, Sheets NH-38-11 and NH-38-12, Scale 1:250 000. GEOSURV, Baghdad.

[9] Deikran, D.B. (1995) The Geology of Suq Al-Shyukh Quadrangle, Sheet NH-38-7, Scale 1:250000. GEOSURV, Baghdad.

[10] Hamza, N.M. (1997) Geomorphological Map of Iraq, Scale 1:1000000. GEOSURV, Baghdad. 
[11] Barwary, A.M., Yacoub, S.Y. and Benni, T.J. (2002) Quaternary Sediments Map of Iraq, Scale 1:1000000. GEOSURV, Baghdad.

[12] Sissakian, V.K. and Ibrahim, F.A. (2005) Geological Hazards Map of Iraq, Scale 1:1000000. GEOSURV, Baghdad.

[13] Jassim, R.Z. and Al-Jiburi, B.M. (2009) Stratigraphy. Iraqi Bulletin of Geology and Mining, 5, 53-76.

[14] Ma'ala, K.A. (2009) Tectonic and Structural Evolution of the Iraqi Southern Desert. Iraqi Bulletin of Geology and Mining, 5, 35-52.

[15] Yacoub, S.Y. (2011) Geomorphology. Iraqi Bulletin of Geology and Mining, 7, 7-32.

[16] Yacoub, S.Y. (2011) Stratigraphy. Iraqi Bulletin of Geology and Mining, 7, 47-82.

[17] Sissakian, V.K. and Fouad, S.F. (2012) Geological Map of Iraq, Scale 1:1000000. 4th Edition, GEOSURV, Baghdad.

[18] Given, J. (2009) The Climatic Paradigm: The Correlation of Climate to Dry Land Alluvial Fan Evolution and Morphology. Geog. 689, Internet Data.

[19] Jassim, S.Z., Karim, S.A., Basi, M.A., Al-Mubarak, M. and Munir, J. (1984) Final Report on the Regional Geological Survey of Iraq, Vol. 3, Stratigraphy. GEOSURV, Internal Report No. 1447.

[20] van Bellen, R.C., Dunnington, H.V., Wetzel, R. and Morton, D. (1959) Lexique Stratigraphic International. Asie, Fasc. 10a, Iraq, Paris.

[21] Jassim, S.Z. and Goff, J. (2006) Geology of Iraq. Dolin and Moravian Museum, Prague, 341.

[22] Sissakian, V.K. and Mohammed, B.S. (2007) Stratigraphy. Iraqi Bulletin of Geology and Mining, 3, 51-124.

[23] Sissakian, V.K. and Deikran, D.B. (1998) Neotectonic Map of Iraq, Scale 1:1000000. GEOSURV, Baghdad, Iraq.

[24] Saito, K. and Ogushi, T. (2005) Slope of Alluvial Fans in Humid Regions of Japan, Taiwan and the Philippines. Geomorphology, 70, 147-162. http://dx.doi.org/10.1016/j.geomorph.2005.04.006

[25] Ghalib, A.A. (1988) Study the Geomorphology of Najaf Plateau. M.Sc. Thesis, University of Baghdad, Baghdad.

[26] Al-Khateeb, A.A.G. and Hassan, K.M. (2005) Detailed Geological Survey for Mineral Exploration in Karbala-Najaf Area. GEOSURV, Internal Report No. 2891.

[27] Sissakian, V.K. and Jab’bar, M.F.A. (2014) The Origin of Tar Al-Sayed and Tar Al-Najf in Karbala—Najaf Vicinity, Central Iraq. Iraqi Bulletin of Geology and Mining, In Progress.

[28] Sissakian, V.K. (2011) Alluvial Fans of Sinjar Mountain, Northwest Iraq. Iraqi Bulletin of Geology and Mining, 7, 926.

[29] Sissakian, V.K. and Jab’bar, M.F.A. (2013) Alluvial Fans of Al-Hab’bariyah Depression, Iraqi Western Desert. Iraqi Bulletin of Geology and Mining, 9, 27-45.

[30] Bull, W.B. (1991) Geomorphic Responses to Climate Change. Oxford University Press, Oxford.

[31] American Geological Institute (1962) Alluvial Fan. Dictionary of Geological Terms. New York, Dolphin Books. Wikipedia, the Free Encyclopedia.

[32] Ritter, D.F., Kochel, R.C. and Miller, J.R. (2002) Process Geomorphology. McGraw Hill Higher Education, 560.

[33] Keller, E.A. and Pinter, N. (2002) Active Tectonics, Earthquakes, Uplift and Landscape. 2nd Edition, Prentice Hall, Upper Saddle River, 362. 